\title{
Peran Informasi Pemasaran pada Usaha Wajik Tape Melayu Provinsi Riau
}

\author{
Sri Maryanti ${ }^{1}$,Nining Sudiar ${ }^{2}$, Afred Suci ${ }^{3}$, Hardi $^{4}$ \\ 1,2,3,4 Universitas Lancang Kuning \\ E-mail: ssrimaryanti@yahoo.com
}

\begin{abstract}
Abstrak
Wajik Tape Melayu merupakan salah satu usaha kecil menengah yang berdiri sejak tahun 2008. Pada awalnya hasil produksi wajik hanya dipasarkan di sekitar Kota Pekanbaru. Sejak tahun 2011, pemasaran produk Wajik Tape Melayu telah merambah ke luar kota, termasuk luar provinsi. Melihat kondisi tersebut penulis tertarik untuk mengkaji tentang peran informasi pemasaran pada usaha Wajik Tape Melayu. Hal ini dilakukan selain untuk mengembangkan usaha masyarakat dan untuk turut serta mengembangkan produk unggulan daerah khas provinsi Riau. Metode yang digunakan adalah kepustakaan atau studi literatur. Hasil penelitian menunjukan bahwa keberadaan dan pemanfaatan informasi pemasaran dapat dilakukan melalui beberapa langkah yaitu mengindentifikasi kebutuhan informasi, mengembangkan informasi, melakukan analisis informasi, pendistribusian dan penggunaan informasi. Dapat disimpulkan bahwa informasi pemasaran memiliki peranan yang sangat penting dalam usaha Wajik Tape Melayu. Beberapa faktor yang mempengaruhi peranan informasi tersebut adalah adanya tekanan persaingan, pertumbuhan pasar, usaha untuk meminimalisir kesalahan, dan meningkatnya harapan konsumen. Informasi penting yang dibutuhkan dalam pengembangan usaha Wajik Tape Melayu antara lain informasi terkait situasi persaingan, kondisi perekonomian, peraturan perundang-undangan, dan kondisi internal perusahaan.
\end{abstract}

Kata Kunci: Peran, Informasi pemasaran, wajik tape

\section{PENDAHULUAN}

Saat ini informasi menjadi sebuah kebutuhan bagi setiap individu, lembaga, organisasi maupun sebuah badan usaha karena informasi dapat dimanfaatkan oleh setiap orang untuk melakukan sebuah tindakan maupun keputusan, tidak terkecuali dalam dunia usaha. Dalam dunia usaha maka informasi menjadi unsur utama dalam pemasaran yang efektif sehingga dapat dikatakan bahwa keberhasilan sebuah produk ada pada sistem informasi. Informasi yang tepat adalah informasi yang isinya sesuai dengan yang dibutuhkan, penyampian yang tepat pada waktu atau saat yang dibutuhkan dan disampaikannya tepat pada tempat adalah informasinya menyeluruh sesuai dengan apa yang dibutuhkan dan tidak kurang.

Keberadaan informasi pemasaran dalam dunia usaha menjadi satu hal yang mutlak. Beberapa menjadi aspek penting dalam pengambilan keputusan bagi para pelaku usaha. Hal ini dikarenakan dengan informasi yang tepat akan mampu menarik konsumen yang tepat dan 'militan' terhadap produk yang dihasilkan. Bahkan, beberapa produsen melakukan penyebaran informasi yang masif dan terstruktur terhadap produk yang dihasilkan kepada konsumen sebelum produk tersebut dipasarkan di masyarakat. 
Kondisi ini menunjukkan bahwa informasi memiliki peran penting dalam dunia usaha.

Selanjutnya perkembangan teknologi telah mendorong perkembangan informasi yang luar biasa. Hal ini perlu disikapi oleh para pelaku usaha, terutama pelaku usaha lokal, dengan memanfaatkan kesempatan dan peluang yang ada untuk meningkatkan usaha mereka. Permasalahan muncul ketika para pelaku usaha lokal yang masih mengandalkan teknologi tradisional dan masih belum melek informasi sehingga menghambat pertumbuhan dunia usaha mereka. Hal ini tentu saja perlu disikapi dengan melakukan pendampingan terhadap pelaku usaha agar lebih melek dan mampu memanfaatkan informasi pemarasan secara optimal guna meningkatkan dunia usaha mereka.

Menurut (Jaidan, 2010) untuk dapat meningkatkan daya saing UKM serta mendapatkan peluang ekspordan peluang bisnis dapat dilakukan dengan memanfaatkan perkembangan Information and Communication Technologi (ICT) utamanya pemanfaatan website dan ecommerce sebagai saran untuk memasarkan produk sehingga akan meningkatkan volume penjualan dan pendapatan.

Wajik Tape Melayu dengan brand Puspa Melayu merupakan salah satu usaha kecil menengah yang berdiri sejak tahun 2008 oleh Dra Puspa Zaitun di Kecamatan Siak Hulu Kabupaten Kampar. Sebagai pengusaha lokal Riau yang tidak hanya menjual produk wajik tape dengan bahan dasar ubi kayu, tetapi juga turut serta mengangkat dan mempertahankan salah satu warisan budaya Melayu yang ada di Riau. Pada awalnya wajik ini hanya diproduksi dengan rasa wijen dan durian. Dalam perkembangannya, berbagai varian rasa berbasis hasil tanaman lokal mulai dikembangkan, seperti nanas, ubi ungu, dan berbagai varian rasa lainnya.

Pemasarannya produk Wajik Tape Melayu pun mengalami perkembangan yang cukup siginifikan. Pada awalnya hasil produksi wajik hanya dipasarkan di sekitar Kota Pekanbaru, seperti Pasar Bawah, Mega Rasa, Red Planet Swalayan, Silungkang, Bolu Gulung Khadijah, Verina Risol, Harum Sari, Cik Puan, Ananda, Hawaii, 999 Swalayan, Mama Mia, Metro, Pisang Kuantan, Mimi Kemojo, dan beberapa outlet yang terdapat di Bandara Sutan Syrif Kasim Pekanbaru. Sejak tahun 2011, pemasaran produk Wajik Tape Melayu telah merambah ke luar kota, termasuk luar provinsi, seperti Pangkalan Kerinci, Taluk Kuantan, Dumai, Duri, Kandis, Bangkinang, Danau Bingkuang, dan Medan.

Namun yang menjadi fenomena dari penelitian ini adalah Usaha Wajik Tape Melayu selama ini memasarkan produk yang dihasilkan melalui Traditional Word of Mouth karena masalah utama dari UMKM adalah pemasaran (Hafsah, 2004), menurut analisa pasar yang telah dilakukan hal ini lebih cepat untuk memasarkan produk mereka yaitu dengan mendatangi langsung target pasar dengn memberikan sampel produk kepada target pasar. Namun kendala lain adalah fihak Wajik Tape Melayu harus menunggu waktu untuk memastikan produk yang mereka tawarkan tersebut dapat diterima atau tidak. Menurut fihak Wajik Tape Melayu pemasaran dengan memanfaatkan media elektronik belum tentu efektif dalam memasarkan produk dan memang harus diperlukan promosi secara tradisional. Oleh karena itu melalui penelitian ini ingin dikethaui seberapa besar peran informasi pemasaran bagi produk yang dihasilkan. Permasalahan dalam penelitian ini adalah apakah informasi pemasaran memiliki peranan dalam

Ekonomi, Sosial, dan Budaya 1026 
memasarkan produk yang dihasilkan? Seberapa besar peningkatan omset dan pendapatan jika menggunakan informasi pemasaran?. Manfaat dari penelitian ini adalah untuk menganalisis peran informasi pemasaran untuk produk yang dihasilkan, seberapa efektif peran informasi pemasaran bagi sebuah produk.

Melihat latar belakang tersebut, penulis tertarik untuk mengkaji tentang peran informasi pemasaran pada usaha Wajik Tape Melayu yang ada di Provinsi Riau. Hal ini dilakukan selain untuk mengembangkan usaha masyarakat juga dilakukan untuk turut serta mengembangkan produk unggulan daerah khas provinsi Riau.

Dalam mengembangkan sebuah usaha dibutuhkan berbagai upaya tidak terkecuali dengan UMKM yaitu sendiri, mengingat UMKM dianggap memiliki prospek pertumbuhan jangka panjang karena terkait dengan pertumbuhan pekerjaan, memiliki dampak terbsear pada daerah setempat dan dapat memanfaatkan keunggulan pasar (Henderson \& Weiler, 2010). Salah satu peningkatan dapat dilakukan melalui penterasi pasar yang memiliki pengaruh siginificance terhadap pemasaran sehingga dalam memasarkan produk harus memiliki strategi untuk kebertahanan pelanggan, program kesetiaan, dan strategi dari pemasaran keterhubungan dengan penetrasi pasar sehingga penetrasi psar mampu memberikan dampak pada kinerja pemarasan yang lebih baik (Harini \& Yulianeu, 2018).

Peran informasi pemasaran untuk UMKM tidak terkecuali pada Usaha Wajik Tapai Melayu tidak terlepas dari peranan teknologi uinformasi. Menurut (Sanjaya, Herliana, Fitriyani, Rahayu, \& Suhartini, 2018) kebutuhan akan manfaat teknologi informasi dapat dikelola dari yang bersifat konvensional menjadi online sehingga mampu untuk mengelola seluruh aktivitas bisnis yang mampu menunjang kinerja dan kualitas UMKM. Dengan meningkatnya kualitas UMKM mampu mewujudkan sila kelima dari Pancasila memalui kebijakan pemberdayaan usaha mikro kecil dan menengah UMKM, dimana UMKM mampu menyerap $96,1 \%$ dari tenaga kerja, kondisi ini belum berkembang secara baik karena masih rendahnya omset dari produk UMKM yaitu $11,3 \%$ sampai $18,2 \%$ dengan pertumbuhan keuntungan/laba hanya berkisar antara $10,9 \%$ sampai $15,3 \%$ hal ini dimungkinkan karena masih kurang berperannya informasi pemasaran untuk produk UMKM (Situmorang, 2015).

Ada beberapa hal yang jarang diperhatikan oleh pemilik usaha, yaitu kebutuhan dan keinginan konsumen karena selama ini konsep pemasaran berorioentasi kepada konsumen, shingga perlu rancangan Tekonologi dan Komunisai (TIK) melalui media internet dimana pemasarannya berbasis ICT sebgai alternatif terbaik media promosi seperti penggunaan WEB (Arbainah, 2014)

Disamping itu pemasaran secara konvesional memerlukan biaya tinggi, misalnya membuka cabang baru, ikut pameran, pembuatan dan penyebaran brosur. Berkembangnya internet menjadi saranayang sangat efisien dalam membuka jalur pemasaran bagi produk UMKm sehingga dapat mempersingkat waktu dan jangkauan lebih luas(Supardi \& Dores, 2009).

("Penggunaan Teknologi Internet Dalam Bisnis," 2000) terus mengalami perkembangan, dari pertukaran informasi secara elektronik ke aplikasi strategi bisnis , seperti pemasaran, penjualan, dan pelayanan pelanggan. Akibat internet pemasaran terhadap perusahaan , produk, dan pelayanan menjadi proses yang interaktif

Ekonomi, Sosial, dan Budaya 1027 
saat ini sehingga konsumen dapat dilibatkan secara langsung dalam perancangan , pengembangan, pemasaran, dan penjualan produk.

\section{METODE}

Penelitian ini mengunakan metode kepustakaan atau studi literatur. Menurut (Danandjaja, 2014) penelitian kepustakaan adalah cara penelitian bibliografi , secara sistematis ilmiah yang meliputi pengumpulan bahan-bahan bibliografi yang berkaitan dengan sasaran penelitian; teknik pengumpulan data dengan metode kepustakaan dan pengorganisasian serta penyajian data-data.

Sebagai bentuk penelitian kepustakaan, penelitian ini dilaksanakan ke dalam beberapa tahap penting, yaitu pemilihan persoalan, penentuan ruang lingkup penelitian, pemeriksaan karya tulis yang bersangkutan, perumusan kerangka teoritis, perumusan konsep-konsep, penentuan hipotesa, pemilihan pelaksanaan metode penelitian, perencanaan sampling namun semua ini tergantung dari penelitian yang akan dilakukan dalam hal ini dilakukan menjadi: persiapan penelitian, menyusun bibliografi kerja, mengatur waktu, dan membuat catatan penelitian (Danandjaja, 2014). Data yang dikumpulkan adalah data sekunder yang berkaitan dengan informasi pemasaran. Hasil pengumpulan data kemudian dikemukakan dalam bentuk deskriptif kualitatif untuk mengambarkan bagaimana peran informasi pemasaran pada usaha Wajik Tape Melayu.

Untuk menganalisis peran informasi pemasaran bagi pada usaha Wajik tape Melayu maka digunakan analisa deskriptif kualitatif yaitu menggunakan data penjualan dan omset penjualan sebelum menggunakan informasi pemasaran dan setelah menggunakan informasi pemasaran, hal ini jug adapt dikaji dari target dan realisasi penjualan produk Wajik Tape Melayu.

\section{HASIL DAN PEMBAHASAN}

Sebagai bagian dari produk lokal, keberadaan Wajik Tape Melayu merupakan suatu usaha dalam mempertahankan warisan budaya masyarakat setempat, sehingga layak dikatakan sebagai produk unggulan daerah. Untuk dapat dikategorikan sebagai unggulan daerah harus memenuhi beberapa kriteria yaitu : mempunyai daya saing yang tinggi di pasaran; Memanfaatkan potensi sumberdaya local yang potensial untuk dikembangkan; mempunyai nilai tambah yang tinggi bagi masyarakat pedesaan ; secara ekonomi menguntungkan dan bermanfaat untuk meningkatkan pendapatan dan kemampuan sumberdaya manusia ; Layak didukung oleh bantuan modal kredit (Sudiar, 2019). Pada sisi ini, Wajik Tape Melayu pada dasarnya memiliki nilai tambah dalam dunia pemasaran. Sebagaimana diketahui bahwa salah satu aspek penting dalam pemasaran adalah lingkungan budaya (Dharmmesta, 2014). Lingkungan ini pada dasarnya melekat pada produk Wajik Tape Melayu yang dihasilkan. Meskipun demikian, pelaku usaha pada bidang ini perlu melakukan upaya agar mampu melakukan pemasaran secara optimal. Oleh karena itu diperlukanlah data berupa informasi pemasaran yang baik agar dapat digunakan dalam pengambilan keputusan.

Informasi pemasaran merupakan bagian penting dalam menunjang efektifitas pemasaran. Informasi pemasran merupakan sekumpulan informasi tentang kondisi pasar yang dapat menggambarkan kondisi aktual terkait ketersediaan dan permintaan suatu 
produk serta faktor-faktor yang berkaitan dengan keduanya (Nuryanti, 2013). Melalui pengelolaan informasi pemasaran yang optimal dapat memberikan gambaran terkait kebutuhan dan keinginan konsumen. Pentingnya informasi dikarenakan pengambilan keputusan terkait produk yang bersangkutan memerlukan informasi yang holistik. Bahkan, pada saat ini informasi tidak hanya berfungsi sebagai masukan dalam pengambilan keputusan, tetapi juga telah menjadi aset dan alat penting dalam pemasaran (Nuryanti, 2013). Oleh karena itu, penguasaan informasi pemasaran menjadi mutlak untuk dapat memenangkan pasar.

Informasi terkait kebutuhan dan keinginan konsumen merupakan hal yang penting dalam memperoleh gambaran tentang perilaku konsumen. Di sisi lain, kepuasan konsumen merupakan tujuan utama dari pemasaran agar dapat mendapatkan pelanggan yang loyal. Pada konsep ini, jika pelaku usaha ingin memperoleh loyalitas melalui pemberian nilai yang terbaik kepada konsumen, maka perlu mengetahui informasi mengenai siapa konsumen yang dilayani dan bagaimana karakteristik perilaku mereka Pada titik ini, informasi menjadi hal yang krusial.

Pentingnya informasi dalam dunia pemasaran didorong oleh beberapa faktor sebagai berikut (Suhari, 2008).

a. Tekanan Persaingan. Dunia usaha tidak akan terlepas dari persaingan usaha. Adanya persaingan telah memaksa pelaku usaha untuk dapat memasarkan produk lebih cepat serta mengembangkannya melebihi dari pesaing mereka. Hal ini dilakukan agar mereka mampu lebih kompetitif dalam dunia usaha. Pada saat ini, usaha Wajik Tape Melayu merupakan produsen utama wajik berbahan dasar tape di wilayah Riau. Hal ini merupakan keuntungan tersendiri mengingat belum ada pesaing lain pada bidang usaha ini. Meskipun demikian, kondisi persaingan tetap perlu untuk diantisipasi terlebih terdapat beberapa wajik yang berbahan dasar selain tape, seperti ketan, kelapa, dan lain-lain.

b. Pasar yang bertumbuh. Dunia usaha adalah dunia yang dinamis. Pelaku usaha harus mampu mengantisipasi pertumbuhan pasar yang ada. Pertumbuhan pasar yang semakin kompleks disertai dengan banyaknya pelaku usaha lain yang turut beroperasi di bidang yang sama menuntut strategi tertentu yang harus dilakukan oleh pelaku usaha agar mampu terus hidup di tengah pertumbuhan pasar yang ada. Keberanian pelaku usaha Wajik Tape Melayu untuk memasarkan produk ke luar kota perlu disertai informasi mengenai kondisi pasar yang ditargerkan.

c. Harga sebuah kesalahan. Pelaku usaha harus mampu untuk terus mengembangkan produk yang ditawarkan. Keberanian untuk mengembangkan dan mengeluarkan produk baru tidaklah mudah. Selain membutuhkan biaya yang tinggi juga akan mempertaruhkan nama besar sebuah perusahaan. Kegagalan dalam pemasaran suatu produk merupakan hal yang harus dihindari. Oleh karena itu, melalui informasi yang tepat akan mengurangi resiko kesalahan. Pengembangan varian baru Wajik Tape Melayu mengharuskan pemilik usaha untuk melakukan riset guna mendapatkan informasi tentang bagaimana produk baru yang akan 
ditawarkan dapat diterima dengan baik oleh konsumen.

d. Harapan konsumen yang meningkat. Perkembangan sosial budaya masyarakat mengakibatkan keinginan dan kebutuhan konsumen semakin berubah. Informasi mengenai konsumen sangat diperlukan untuk memahami berbagai harapan konsumen yang semakin spesifik. Kesalahan dalam menganalisa kebutuhan dan keinginan konsumen dapat mengakibatkan kegagalan dalam pemasaran suatu produk. Konsumen tidak akan berhenti pada varian produk Wajik Tape Melayu yang telah ada. Mereka selalu memiliki keinginan yang selalu berkembang sehingga perlu diantisipasi dengan mengumpulkan informasi terkait keinginan konsumen.

Pentingnya informasi sebagaiman telah dijelaskan di atas mengindikasikan bahwa keberadaan informasi pemasaran tidak akan terlepas dari berbagai kegiatan usaha. Keberadaan informasi pemasaran perlu dimanfaatkan secara optimal. Pemanfaatan tersebut dapat dilakukan melalui beberapa langkah sebagai berikut.

\section{Identifikasi Kebutuhan informasi}

Berbagai informasi dapat diperoleh oleh pelaku usaha. Namun, tidak semua informasi yang diperoleh nantinya berguna dalam memasarkan produk yang mereka hasilkan. Informasi yang diperoleh haruslah seimbang dengan informasi yang dibutuhkan. Oleh karena itu, pelaku usaha perlu melakukan identifikasi terhadap informasi pemasaran apa saja yang dibutuhkan.

Informasi penting yang harus diperoleh dalam proses pemasaran adalah sebagai berikut (Susanto \& Wijanarko, 2004).

- Situasi persaingan. Pelaku usaha Wajik Tape Melayu harus memiliki informasi terkait situasi persaingan produk sejenis. Hal ini diperlukan dalam rangka menentukan posisi saing produk yang dihasilkan. Informasi terkait pelaku usaha lain yang memproduksi wajik merupakan aset penting yang harus dimiliki. Informasi ini tidak hanya terbatas pada pelaku usaha wajik yang berada di wilayah Pekanbaru saja, tetapi produsen lain yang berada di Kabupaten/Kota di Provinsi Riau bahkan di luar kota.

- Kondisi perekonomian. Pengetahuan terkait kondisi perekonomian penting untuk dimiliki oleh seorang pelaku usaha. Pengetahuan tersebut sangat berguna dalam menentukan harga dan tingkat peminatan pasar terhadap suatu produk. Berdasarkan Berita Resmi Statistik, pertumbuhan ekonomi di Provinsi Riau pada tahun 2018 mengalami pertumbuhan sebesar 2,34\% (Badan Pusat Statistik Provinsi Riau, 2019). Informasi terkait kondisi ekonomi ini penting untuk dijadikan sebagai referensi dasar dalam mengelola produksi serta harga pasar Wajik Tape Melayu.

- Peraturan perundang-undangan. Pemasaran suatu produk selain memberikan sisi positif ternyata juga memiliki dampak negatif bagi masyarakat. Salah satu dampak negatif tersebut adalah bahwa pemasaran memiliki potensi terjadinya deceive (Harini \& Yulianeu, 2018). Untuk mengontrol efek negatif dari pemasaran, maka pemerintah telah mengeluarkan sejumlah regulasi yang

Ekonomi, Sosial, dan Budaya 1030 
harus dipatuhi oleh setiap produsen suatu produk. Pelaku usaha Wajik Tape Melayu juga harus memahami setiap regulasi yang dikeluarkan oleh pemerintah terkait produk yang mereka tawarkan. Setiap produk yang dihasilkan dan dipasarkan ke konsumen haruslah produk-produk yang tidak bertentangan dengan ketentutan perundang-undangan yang berlaku, baik dari segi proses maupun dari segi hasil. Oleh karena itu, informasi terkait perkembangan peraturan perundang-undangan yang berlaku penting untuk dimiliki oleh pelaku usaha Wajik Tape Melayu.

- Kondisi intern perusahaan. Selain mengetahui kondisi eksternal dalam pemasaran, pelaku usaha Wajik Tape Melayu juga harus memiliki informasi tentang kondisi internal perusahaan. Informasi terkait kondisi internal perusahaan dapat digunakan untuk menilai sumberdaya yang dimiliki pelaku usaha untuk menjalankan perusahaan (Bhardwaj, 2017). Oleh karena itu, pelaku usaha Wajik Tape Melayu perlu mengetahui kondisi lingkung internal perusahaan, seperti operasional pemasaran, data penjualan, pangsa pasar yang telah ada, margin keuntungan/biaya, dan bauran pemasaran.

\section{Pengembangan Informasi}

Keberadaan informasi yang berkualitas mutlak dimiliki oleh pelaku usaha Wajik Tape Melayu. Kualitas informasi tersebut akan mempengaruhi pengambilan keputusan yang strategis. Oleh karena itu, informasi pelaku usaha perlu melakukan pengembangan informasi. Pengembangan informasi dapat dilakukan dengan melihat beberapa hal sebagai berikut (Kenny \& Marshall, 2000).

- Catatan internal. Catatan internal merupakan sistem pencatatan yang dihasilkan dari kegiatan suatu dunia usaha. Hal tersebut dapat berupa catatan dari bagian penjualan, keuangan, maupun akuntansi suatu perusahaan.

- Intelijen pemasaran. Persaingan yang muncul mendorong pelaku usaha untuk mengetahui informasi penting terkait kondisi pesaing. Meskipun Wajik Tape Melayu secara produk belum memiliki pesaing berbahan dasar yang sama, namun keberadaan wajik dengan bahan dasar lain perlu diangap sebagai pesaing. Intelijen pemasaran merupakan suatu bagian dari suatu perusahaan yang bertugas untuk mengidentifikasi keberadaan dan posisi pesaing suatu usaha. Bagian tersebut bertugas untuk menginformasikan persaingan dan lingkungan pemasaran untuk pengambilan keputusan yang tepat. Pada praktiknya, pelaku usaha Wajik Tape Melayu tidak harus mendirikan bagian intelijen guna menghasilkan informasi tersebut. Hal ini dikarenakan pada dasarnya setiap bagian yang menjadi pegawai dapat menjadi intelijen pemasaran dengan melakukan fungsi ganda, yaitu melaksanakan tugas kesehariannya sekaligus menjalankan fungsi intelijen.

- Riset pemasaran. Pelaku usaha dapat melakukan riset pemasaran guna memperoleh informasi pemasaran yang dibutuhkan. Kegiatan riset pemasaran dapat dilakukan oleh bagian riset tersendiri dalam suatu perusahaan ataupun berkolaborasi

Ekonomi, Sosial, dan Budaya 1031 
dengan bagian riset yang berada di luar perusahaan. Salah satu langkah yang telah dilakukan oleh pelaku usaha Wajik Tape Melayu adalah berkolaborasi dengan peneliti yang berasal dari perguruan tinggi sebagaimana yang penulis lakukan guna melakukan riset pemasaran.

\section{Analisis Informasi}

Setelah seluruh informasi yang dibutuhkan telah terkumpul, maka langkah selanjutnya adalah melakukan analisis informasi. Seluruh data yang terkumpul disaring dan disesuaikan dengan kebutuhan yang ada. Analisis informasi dapat dilakukan melalui analisis kualitatif ataupun analisis kuantitatif(Arbainah, 2014). Pelaku usaha Wajik Tape Melayu perlu melakukan analisis terhadap informasi yang diperoleh guna memperoleh gambaran pasar yang ada. Pasar yang digambarkan tidak hanya pasar lokal saja, tetapi juga peluang pasar global untuk produk Wajik Tape Melayu.

\section{Distribusi dan Penggunaan Informasi}

Informasi pemasaran yang diperoleh tidak akan berguna selama informasi tersebut masih 'berdiam diri' dan tersimpan di bank data. Agar bermanfaat secara optimal, informasi pemasaran yang diperoleh harus didistribusikan dan digunakan oleh pelaku usaha. Pelaku usaha Wajik Tape Melayu merupakan masyarakat tempatan yang masih mengedepankan teknologi tradisional dalam produksinya. Oleh karena itu penyajian informasi pemasaran tidak harus dalam bentuk angkaangka yang membingungkan. Informasi pemasaran dapat disajikan secara sederhana sehingga mudah dipahami. Melalui penggunaan informasi pemasaran yang tepat dapat meningkatkan produksi dan menunjungan optimalisasi pemasaran Wajik Tape Melayu.
Jika dianalisis peran informasi dalam pemasaran dapat meningkatkan pendapatan dalam sebuah usaha, untuk studi kasus pada wajik tape melayu yang sebelumnya memasarkan produk yang dihasilkan secara langsung dan menghasilkan menghasilkan kapasitas produksi dari Wajik Tapai "Melayu" diukur dalam satuan $\mathrm{Kg}$ /Proses Produksi. Rata-rata produksi wajik Tapai "Melayu" $9.022 \mathrm{Kg} /$ Proses dengan harga rata-rata produksi wajik/kg sebesar $\mathrm{Rp}$ 49.377,- dengan rata-rata pendapatan kotor Rp 449.278.900,- dan pendapatan bersih rata-rata Rp 166.966.212,- bahan baku yang digunakan $26 \mathrm{~kg}$ ubi kayu dan Jumlah tenaga kerja adalah 7 orang. Untuk jumlah biaya investasi dalam usaha Wajik Tapai “ Melayu" rata-rata $\mathrm{Rp}$ 26.073.232,34,dengan rata-rata biaya operasional $\mathrm{Rp}$ 256.239.455,42,- jadi untuk total biaya produksi yang dikeluarkan dalam usaha Wajik Tapai"Melayu" adalah Rp 282.312.687,76.

Namun setelah menggunakan media informasi kapasitas penjualan dari produk wajik tape melayu terus mengalami penimgkatan terutama prospek usaha Wajik Tapai Melayu sangatlah menguntungkan sehingga sangat berpeluang jika dikembangkan menjadi produk unggulan daerah selain dan menambah income daerah serta mengatasi masalah pengangguran yang ada di Riau. Hasil perhitungan analisis financial keempat criteria investasi menunjukkan bahwa usaha Wajik Tapai "Melayu" menguntungkan dimana nilai investasi akan kembali selama 2 tahun 3 bulan, seperti yang tercantum pada lampiran tabel 1.

Berdasarkan hasil analisis selama kurun waktu 2014-2019 laba bersih dari usaha wajik tape melayu terus mengalami peningkatan dari 120 juta meingkat sampai 185 juta dengan margin keuntungan dari

Ekonomi, Sosial, dan Budaya 1032 
$31 \%$ meningkat menjadi $34 \%$ setelah menggunakan informasi pemasaran, artinya peningkatan laba bersih sebelum menggunakan informasi pemasran dinilai tidak terlalu significance sedangkan setelah menggunakan system informasi mampu meningkatkan labaa bersih dari wajik tape melayu. Artinya setiap usaha jika ingin memperluas area pemasarannya maka hendaknya setiap usaha menggunakan informasi pemasaran karena mampu meningkatkan pendapatan usaha dan laba bersih seperti yang tercantum pada table 2 di lampiran.

\section{SIMPULAN, KETERBATASAN DAN SARAN}

\section{Simpulan}

Berdasarkan pemaparan di atas dapat disimpulkan bahwa informasi pemasaran memiliki peranan yang sangat penting dalam usaha Wajik Tape Melayu. Beberapa faktor yang mempengaruhi peranan informasi tersebut adalah adanya tekanan persaingan, pertumbuhan pasar, usaha untuk meminimalisir kesalahan, dan meningkatnya harapan konsumen. Informasi penting yang dibutuhkan dalam pengembangan usaha Wajik Tape Melayu antara lain informasi terkait situasi persaingan, kondisi perekonomian, peraturan perundangundangan, dan kondisi internal perusahaan. Penelitian ini merupaka kajian sederhana yang bersifat teoritis terhadap peranan informasi pemasaran pada usaha Wajik Tape Melayu. Perlu dilakukan kajian yang lebih mendalam dan aplikatif terhadap peranan informasi pemasaran terhadap suatu perusahaan. Melalui kajian secara holistik diharapkan mampu memberikan gambaran yang lebih nyata dan aplikatif terhadap peranan informasi pemasaran pada suatu usaha. Dengan menggunakan informasi pemasaran maka mampu meningkatkan laba bersih dan nilai inevstasi sebuah usaha seperti yang dilakukan oleh wajik tape melayu yang awalnya tidak menggunakan informasi pemasaran namun setelah menggunakan informasi pemasaran maka mampu meningkatkan margin keuntungan sampai $34 \%$ dengan nilai investasi yang dapat kembali 2 atau 3 tahun.

\section{Saran}

Penelitian ini diharapkan dapat bermafaat bagi UMKM yang ada di Provinsi Riau bukan hanya Wajik Tapai Melayu saja atau bukan hanya UMKM yang bergerak dibidang produk pangan saja. Diharapkan pemerintah daerah Provinsi Riau mampu membantu UMKM yang ada di Riau sehingga dapat bersaing dengan produkproduk pangan yang telah menjamur di Indonesia yang mengalahkan produk pangan yang berasal dari Indonesia.

\section{Keterbatasan}

Untuk peneliti berikutnya yang ingin mengembangkan penelitian ini dapat mengkaji lebih mendalam terhadap peran informasi bagi UMKM yang ada di Indonesia untuk menembus pasar global sehingga UMKM dapat menemukan role untuk mengembangkan usaha mereka.

\section{UCAPAN TERIMAKASIH}

Penulis mengucapkan terimakasih kepada Kementerian Riset Teknologi dan Pendidikan Tinggi Republik Indonesia yang telah menyediakan pendanaan pengabdian tahun 2020. Tidak lupa penulis ucapkan terimakasih kepada Universitas Lancang Kuning melalui LPPM yang telah memfasilitasi jalannya penelitian ini. Penulis juga mengucapkan terimakasih kepada seluruh pihak yang ikut terlibat di dalam 
kegiatan penelitian ini yang tidak dapat penulis sebutkan satu persatu.

\section{DAFTAR PUSTAKA}

Arbainah, S. (2014). Pemasaran Bersama Berbasis ICT Sebagai Media Promosi Alternatif Bagi UMKM Desa Wisata. Jabpi.

Bhardwaj, D. (2017). The new rules of marketing and PR: How to use social media, online video, mobile applications, blogs, news releases, and viral marketing to reach buyers directly by David Merman Scott . Journal of Information Technology Case and Application Research. https://doi.org/10.1080/15228053.2017. 1362848

Danandjaja, J. (2014). Metode Penelitian Kepustakaan. Antropologi Indonesia. https://doi.org/10.7454/ai.v0i52.3318

Dharmmesta, B. S. (2014). Peran Pemasaran dalam Perusahaan dan Masyarakat. Marketing Management.

Hafsah, M. J. (2004). Upaya Pengembangan Usaha Kecil Dan Menengah (UKM). Infokop Nomor 25.

Harini, C., \& Yulianeu, Y. (2018). Strategi penetrasi pasar UMKM Kota Semarang menghadapi era pasar global MEA. Jurnal Ekonomi Dan Bisnis. https://doi.org/10.24914/jeb.v21i2.1967

Henderson, J., \& Weiler, S. (2010). Entrepreneurs and job growth: Probing the boundaries of time and space. Economic Development Quarterly. https://doi.org/10.1177/0891242409350 917

Jaidan, J. (2010). Upaya Pengembangan Usaha Kecil Menengah (UKM) Dengan Memanfaatkan E-Commerce. Jurnal Sistem Informasi. https://doi.org/ISSN
Online : 2355-4614

Kenny, D., \& Marshall, J. F. (2000). Contextual marketing--the real business of the Internet. Harvard Business Review.

Nuryanti. (2013). Peran E-Commerce Untuk Meningkatkan Daya Saing Usaha Kecil dan Menengah ( UKM ). Jurnal Ekonomi Manajemen Ekonomi Universitas Riau. https://doi.org/10.1073/pnas.07039931 04

PENGGUNAAN TEKNOLOGI INTERNET DALAM BISNIS. (2000). Jurnal Akuntansi Dan Keuangan. https://doi.org/10.9744/jak.2.1.pp.36-52

Sanjaya, R., Herliana, A., Fitriyani, Rahayu, Y. S., \& Suhartini, T. (2018). Sistem Informasi Manajemen Bisnis dan Keuangan UMKM Menggunakan Model MVC Pada Framework Laravel. Jurnal Abdimas BSI.

Situmorang, J. (2015). Strategi UMKM dalam menghadapi iklim usaha yang tidak kondusif. Infokop.

Sudiar, N. (2019). Konsep OVOP Untuk Mengidentifikasi Produk Unggulan Daerah (Studi Kasus Wajik Tapai Melayu). Dinamisia: Jurnal Pengabdian Kepada Masyarakat. https://doi.org/10.31849/dinamisia.v3i0 .2864

Suhari, Y. (2008). Keputusan Membeli Secara Online dan Faktor-Faktor yang Mempengaruhinya. Jurnal Teknologi Informasi DINAMIK.

Supardi, J., \& Dores, V. (2009). Rancang Bangun Collaborative System Pemasaran Hotel Secara on-Line Dengan Pendekatan Mediator Based. Sistem Informasi (JSI). 